\title{
News on Climate Change, Air Pollution, and Allergic Triggers of Asthma
}

\author{
D'Amato $\mathrm{M}^{1}$, Cecchi L², Annesi-Maesano I', D'Amato G4 \\ 'First Division of Pneumology, High Speciality Hospital "V. Monaldi" and University "Federico II" Medical School, Napoli, Italy \\ ${ }^{2}$ Interdepartmental Center of Bioclimatology, University of Florence, Italy \\ ${ }^{3}$ Epidemiology of Allergic and Respiratory Diseases Department, IPLESP, INSERM \& UPMC Paris6, Sorbonnes Universités, Medical School Saint- \\ Antoine, Paris, France \\ ${ }^{4}$ Division of Respiratory and Allergic Diseases, Department of Respiratory Diseases, High Specialty Hospital A.Cardarelli and University of Napoli \\ Federico II, School of Specialization in Respiratory Diseases, Naples, Italy
}

J Investig Allergol Clin Immunol 2018; Vol. 28(2): 91-97

doi: $10.18176 /$ jiaci.0228

\begin{abstract}
The rising frequency of obstructive respiratory diseases during recent years, in particular allergic asthma, can be partially explained by changes in the environment, with the increasing presence in the atmosphere of chemical triggers (particulate matter and gaseous components such as nitrogen dioxide and ozone) and biologic triggers (aeroallergens). In allergic individuals, aeroallergens stimulate airway sensitization and thus induce symptoms of bronchial asthma.

Over the last 50 years, the earth's temperature has risen markedly, likely because of growing concentrations of anthropogenic greenhouse gas. Major atmospheric and climatic changes, including global warming induced by human activity, have a considerable impact on the biosphere and on the human environment.

Urbanization and high levels of vehicle emissions induce symptoms of bronchial obstruction (in particular bronchial asthma), more so in people living in urban areas compared than in those who live in rural areas. Measures need to be taken to mitigate the future impact of climate change and global warming. However, while global emissions continue to rise, we must learn to adapt to climate variability.

Key words: Air pollution and obstructive respiratory diseases. Airway hyperreactivity in asthma. Air pollution and asthma. Climate change
\end{abstract} and asthma. Climate change and respiratory allergy. Thunderstorm asthma.

\section{Resumen}

La creciente frecuencia de enfermedades respiratorias obstructivas, en particular del asma alérgica, observada en los últimos años, puede explicarse parcialmente por diversos cambios ocurridos en el medio ambiente, con presencia creciente en la atmósfera de sustancias químicas (material particulado y componentes gaseosos como dióxido de nitrógeno y ozono) y por factores desencadenantes biológicos (aeroalérgenos). Los aeroalérgenos son capaces de estimular, en sujetos alérgicos, la reactividad de las vías respiratorias, induciendo síntomas de asma bronquial.

En los últimos 50 años, la temperatura global de la tierra ha aumentado notablemente debido a la creciente emisión de concentraciones de gases de efecto invernadero generados por la actividad humana. Los principales cambios que afectan a la atmósfera y al clima, incluido el calentamiento global, tienen un gran impacto en la biosfera y en nuestro entorno.

El incremento de las áreas residenciales y los altos niveles de emisiones vehiculares inducen síntomas de enfermedades que cursan con obstrucción bronquial (en particular asma bronquial), con mayor prevalencia en personas que viven en áreas urbanas en comparación con aquellos que viven en áreas rurales. Se deben aplicar medidas que mitiguen estos factores para reducir los impactos futuros del cambio climático y el calentamiento global en nuestro planeta. Mientras que las emisiones globales continúen aumentando, deberemos adaptarnos a los impactos de la variabilidad climática futura.

Palabras clave: Contaminación del aire y enfermedades respiratorias obstructivas. Hiperreactividad de las vías respiratorias en el asma. Contaminación del aire y asma. Cambio climático y asma. Cambio climático y alergia respiratoria. Asma de las tormentas. 


\section{Introduction}

The massive increase in chemical and biologic pollutants in the atmosphere during the last century has made air quality a major environmental problem in many regions of the world. The negative impact of poor air quality on human health is now well known, and several studies have examined the association between air pollutants and human health, both in the short term and in the long term [1-16].

The prevalence of obstructive airway diseases such as asthma has increased to epidemic proportions worldwide. Besides air pollution from industry-derived emissions and motor vehicles, this increasing trend is due to profound changes in the areas where we live, in both developed and developing countries [1-6]. Asthma and chronic obstructive pulmonary disease (COPD) are among the 10 leading chronic conditions. Both restrict activity, generate substantial consumption of health care resources, and create a considerable economic burden for patients and managed care plans. Asthma is a chronic inflammatory disorder characterized by reversible airflow obstruction and hyperresponsiveness. The Global Initiative for Asthma (GINA) report on the burden of asthma estimated that asthma is one of the most common chronic diseases in the world, affecting 300 million people [7].

The total costs of asthma for the European Union are estimated at $€ 3$ billion [7].

Air pollution significantly affects health, causing up to 7 million premature deaths annually with an even larger number of hospitalizations and days of sick leave. Climate change could alter the dispersion of primary pollutants, especially particulate matter (PM), and intensify the formation of secondary pollutants, such as ozone [1,12,14,17-26].

The world economy has been transformed over the last 50 years, with developing countries being at the core of these changes, many of which are considered to have negative effects on respiratory health and to increase the frequency and severity of respiratory diseases such as asthma in the general population. Increased atmospheric concentrations of greenhouse gases, especially carbon dioxide $\left(\mathrm{CO}_{2}\right)$, have warmed the planet substantially, leading to variability in temperature, increased air pollution, forest fires, droughts, floods, thunderstorms, and more severe and prolonged heat waves, all of which can put the respiratory health of the public at risk [1-3].

Changes in climate and air quality (both outdoors and indoors) have a measurable impact on the morbidity and mortality of patients with asthma and other obstructive respiratory diseases such as COPD. There is also considerable

Table 1. Detrimental Effects of Chemical Air Pollutants on the Airways

- Increased permeability of airway epithelium

- Reduced ciliary activity of airway epithelial cells

- Inflammatory changes in airway cells

- Modulation of the cell cycle and cell death in the airways evidence that individuals affected by asthma are at increased risk of developing chronic obstructive airway exacerbations with continuous exposure to the gaseous and particulate components of air pollution.

Global warming is expected to affect the start, duration, and intensity of the allergenic pollen season. It is also expected to influence the rate of asthma exacerbations due to air pollution, respiratory infections, cold air inhalation, and other conditions [1-6,21,22]. Control of the environment must address both indoor and outdoor exposure to allergens. A reduction in outdoor and indoor air pollution can help to improve the symptoms of obstructive respiratory diseases such asthma and thus reduce disease burden.

\section{Components of Outdoor Air Pollution in Urban Areas}

The negative effect of urban air pollution (chemical and biological) on human health and on respiratory diseases is well known. Epidemiologic studies have demonstrated that urbanization, high levels of vehicle emissions, and a western lifestyle are correlated with an increase in the frequency of the obstructive respiratory diseases that affect people who live in urban areas compared with those who live in rural areas $[1,6,7,27]$ (Table 1$)$. Air pollutants may not only increase the frequency and intensity of symptoms in previously allergic patients, but may also promote airway sensitization to airborne allergens in predisposed persons. Through interaction with pollen grains and plant-derived particles, pollutants can modify the morphology of antigen-carrying agents and alter their allergenic potential. In addition, by inducing airway inflammation, pollutants may overcome the mucosal barrier and therefore "prime" allergen-induced responses. In other words, airway mucosal damage and impaired mucociliary clearance induced by air pollution may facilitate access of inhaled allergens to the cells of the immune system.

Air pollutants exert their proinflammatory effects on airways by causing direct cellular injury or by inducing intracellular signaling pathways and transcription factors that are known to be sensitive to oxidative stress [22-28]. Reduced exposure to air pollution for prevention of asthma can be approached at policy level through reduction in indoor and outdoor air pollution and in lifestyle adjustments for asthmatic persons.

The most abundant components of air pollution in urban areas are $\mathrm{PM}$, nitrogen dioxide $\left(\mathrm{NO}_{2}\right)$, and ozone $\left(\mathrm{O}_{3}\right)$ [22-29].

\section{Chemical Air Pollutants $\left(P M, \mathrm{NO}_{2}\right.$, and $\left.\mathrm{O}_{3}\right)$}

PM is a mixture of organic and inorganic solid and liquid particles of different origin, size, and composition $[22,23,27]$. Ultrafine PM, with diameters of $0.1 \mathrm{~mm}$ or less, is a major component of vehicle emissions. These particles accumulate into larger fine particulate matter with a diameter of $\leq 2.5 \mathrm{~mm}\left(\mathrm{PM}_{2.5}\right)$, within short distances from the point of release. $\mathrm{PM}_{10}$ consists of $\mathrm{PM}_{2.5}$ and larger particles of mainly crystal or biological origin, including many aeroallergens. Epidemiological and laboratory studies [24-27] indicate that $\mathrm{PM}_{2.5}$ is a more potent cause of respiratory and cardiovascular disease than $\mathrm{PM}_{10}$. $\mathrm{PM}_{10}$ can penetrate the lower airways, and 
$\mathrm{PM}_{2.5}$ is thought to constitute a notable health risk because it can be inhaled more deeply into the lungs at the level of the alveoli. Although human lung parenchyma retains $\mathrm{PM}_{2.5}$, particles larger than $5 \mathrm{~mm}$ and smaller than $10 \mathrm{~mm}$ reach the proximal airways only, wherein they are eliminated by mucociliary clearance if the airway mucosa is intact. A large portion of urban PM originates from diesel engines. Diesel exhaust particles (DEPs), which include other components such as polycyclic aromatic hydrocarbons, account for up to $90 \%$ of airborne PM in the world's largest cities. DEPs are composed of fine $(2.5-0.1 \mathrm{~mm})$ and ultrafine $(0.1 \mathrm{~mm})$ particles, which can coalesce to form aggregates of varying sizes. $\mathrm{PM}_{10}$ levels have been associated with early respiratory exacerbations in children with persistent asthma and with higher prevalence rates even after dispersion of the particles. Although there is compelling evidence that ambient air pollution exacerbates existing asthma, the link with the development of asthma syndrome remains less well established, as few studies provide extensive exposure data. The mechanisms whereby fine particles induce adverse effects appear to affect the balance between antioxidant pathways and airway inflammation. Gene polymorphisms involved in antioxidant pathways can modify responses to air pollution. Acute exposure to diesel exhaust causes specific effects such as irritation of the nose and eyes, headache, lung function abnormalities, respiratory changes, fatigue, and nausea, whereas chronic exposure is associated with cough, sputum production, and diminished lung function. Inflammation in the airways has been observed in healthy individuals after exposure to diesel exhaust and DEPs [22,23-27], and elevated expression and concentrations of inflammatory mediators have also been observed in the respiratory tract after exposure to diesel exhaust and DEPs. Carlsten et al [27] recently observed that inhalation of DEP at environmentally relevant concentrations augments allergen-induced allergic inflammation in the lower airways of atopic individuals. DEPs in particular not only enhance the allergen-induced increase in airway eosinophils, IL-5, and eosinophil cationic protein, but also increase levels of markers of nonallergic inflammation and monocyte chemotactic protein 1 and suppress activity of macrophages and myeloid dendritic cells [27].

Open biomass burning also plays an important role in atmospheric pollution and in climate change.

$\mathrm{NO}_{2}$ is a precursor of the photochemical smog found in urban and industrial regions and is most often generated by car and truck exhausts, together with emissions from power plants. In conjunction with sunlight and hydrocarbons, $\mathrm{NO}_{2}$ results in the production of $\mathrm{O}_{3}$. Like $\mathrm{O}_{3}, \mathrm{NO}_{2}$ is an oxidizing pollutant, but with lower chemical reactivity than $\mathrm{O}_{3}$. Exposure to $\mathrm{NO}_{2}$ is associated with more frequent emergency room visits, wheezing, and medication use among children with asthma $[1,2,6,14]$. Controlled exposure studies on asthmatic patients have shown that $\mathrm{NO}_{2}$ can enhance the allergic response to inhaled allergens, and $\mathrm{NO}_{2}$ concentrations in ambient air are also reportedly associated with cough, wheezing, and shortness of breath in atopic patients $[1-3,16]$.

$\mathrm{O}_{3}$ is generated at ground level by photochemical reactions involving $\mathrm{NO}_{2}$, hydrocarbons, and ultraviolet radiation. Tropospheric $\mathrm{O}_{3}$ is formed in the presence of bright sunshine and high temperatures by the reaction between volatile organic compounds and nitrogen oxides, both of which are emitted from natural and anthropogenic sources. An association between tropospheric $\mathrm{O}_{3}$ concentrations and temperature has been demonstrated from measurements in outdoor smog chambers and from measurements in ambient air [29-31].

Inhalation of $\mathrm{O}_{3}$ induces epithelial damage and inflammatory responses in the upper and lower airways, as shown by increased levels of inflammatory cells and mediators in nasal and bronchoalveolar lavage [29-32]. Exposure to increased atmospheric levels of $\mathrm{O}_{3}$ impairs lung function, increases airway hyperreactivity to bronchoconstrictor agents, and is related to an increased risk of asthma exacerbations in asthmatic patients. Epidemiologic studies have provided evidence that high ambient concentrations of $\mathrm{O}_{3}$ are associated with an increased rate of asthma exacerbations, hospital admissions, and/or emergency department (ED) visits for respiratory diseases, including asthma. Furthermore, $\mathrm{O}_{3}$ is thought to increase asthma morbidity by enhancing airway inflammation and epithelial permeability. It has been speculated for some time that $\mathrm{O}_{3}$ and other pollutants may render allergic-atopic patients more susceptible to the antigen they are sensitized to. Beck et al [29] observed that high environmental $\mathrm{O}_{3}$ levels enhance the allergenicity of birch pollen, which is clinically relevant for susceptible individuals. The acute health effects of exposure to ambient $\mathrm{O}_{3}$ have been examined in many geographical regions. Potential adverse effects include decrease in lung function, airway inflammation, symptoms of asthma, more frequent hospitalization due to respiratory diseases, and excess mortality. Exposure to $\mathrm{O}_{3}$ has both a priming effect on allergen-induced responses and an intrinsic proinflammatory effect on the airways of allergic (atopic) asthmatic patients. In the long term, continuous exposure to high $\mathrm{O}_{3}$ levels impairs respiratory function and causes or exacerbates airway inflammation in healthy individuals and in asthma patients. At the population level, long-term exposure to $\mathrm{O}_{3}$ may reduce lung function in schoolchildren and adults and increase the prevalence of asthma and asthmatic symptoms. In addition, studies have shown that asthma can be exacerbated by $\mathrm{O}_{3}$, as measured by increased visits to EDs on days with higher levels of $\mathrm{O}_{3}$ and other pollutants. Malig et al [30] recently explored the association between $\mathrm{O}_{3}$, asthma, and visits to the ED for respiratory complaints. A multicenter, time-stratified case-crossover study of $\mathrm{O}_{3}$ exposures for approximately 3.7 million respiratory ED visits from 2005 through 2008 was conducted among residents living within $20 \mathrm{~km}$ of an $\mathrm{O}_{3}$ monitor in California, USA. The result was that short-term $\mathrm{O}_{3}$ exposure was positively associated with ED visits for asthma, acute respiratory infections, pneumonia, COPD, and upper respiratory tract inflammation. The associations were typically stronger and more consistent during the warm season. As a result of climate change, $\mathrm{O}_{3}$ - and fine particle-related mortality are expected to increase. However, results differ by region, assumed climate change scenario, and other factors, such as population and background emissions.

\section{Biological Outdoor Triggers of Bronchial Obstruction in Asthma: Allergens}

Allergic asthma can be induced by molds and pollens. 


\section{Molds}

There are many mold species, although very few have been well studied with regard to their effects on asthma. Molds can be found in both indoor and outdoor environments $[1,22]$. Aspergillus and Penicillium species are among the most common indoor molds, and Alternaria can be found both indoors and outdoors.

Sensitization to molds has been associated with increased severity of asthma, death, hospital admissions, and intensive care admissions in adults and with increased bronchial reactivity in children [1].

The pathogenic mechanisms by which some mold allergens induce more severe airway disease than other common allergens are unclear. One possible explanation is that, compared with other allergens, molds have the additional ability to actively germinate and infect host skin or to colonize the respiratory tract. It has been suggested that mold allergens acting in concert with other nonallergen proteins or toxins produce an enhanced host response $[1,21,26]$. When outdoors, patients should avoid heavy exposure to moldy vegetation and use a well fitting particulate respirator when working with moldy material. Although there have been no randomized trials on mold abatement in persons with asthma, there is adequate evidence to recommend these basic interventions to reduce exposure in mold-sensitized patients with asthma.

\section{Pollens}

$$
\text { pollen }
$$

Effects of climate change on air pollution and allergenic

Climate change can affect air pollutant levels in several ways. The influence on regional weather (changes in wind patterns and amount and intensity of precipitation, increased temperatures) may have an effect on the severity and frequency of air pollution episodes and also on anthropogenic emissions (eg, increased energy demand for heating and air conditioning). The increased urban heat effect may increase levels of some secondary pollutants (eg, ozone), and can indirectly increase natural sources of air pollutant emissions (eg, decomposition of vegetation, soil erosion, and wildfires) [1]. Pollen from birch exposed to high ozone levels more frequently induces larger wheals and flares in skin prick tests than pollen from birch exposed to low ozone levels, suggesting that ozone increases allergenicity [29]. Changes in temperature and precipitation may also increase the frequency and severity of forest fires, sometimes with public health consequences. Changes in wind patterns may increase long-distance transport of pollutants and pollen grains, making large-scale circulation patterns as important as regional ones [1].

Climate change appears to induce an increased concentration of all health-related air pollutants and influences not only the levels and the type of air pollution, but also allergenic pollens. Global warming affects the onset, duration, and intensity of the pollen season, as well as the allergenicity of pollen. Studies on plant responses to elevated atmospheric levels of $\mathrm{CO}_{2}$ indicate that plants exhibit enhanced photosynthesis and reproductive effects and produce more pollen [1]. Moreover, the plants flower earlier in urban areas (earlier pollination of about 2-4 days) than in rural areas. During the last few decades, many studies have shown changes in production, dispersion, and allergen content of pollen and spores and that the nature of the changes may differ with regions and species. Current knowledge on the worldwide effects of climate change on respiratory allergic diseases is from studies on the relationship between asthma and environmental factors, such as meteorological variables, airborne allergens, and air pollution. Published data suggest a more marked effect of aeroallergens on allergic patients, increasing the likelihood of allergic respiratory disease in sensitized patients and exacerbation in already symptomatic patients [1].

\section{Thunderstorm Asthma and Risk of Asthma Attack}

Current climate change scenarios indicate that there will be an increase in the intensity and frequency of heavy rainfall episodes, including thunderstorms. Thunderstorm asthma is the term used to describe an observed increase in cases of acute bronchospasm following the occurrence of thunderstorms during pollen seasons [31-38]. Associations between thunderstorms and asthma morbidity have been identified in multiple locations around the world, predominantly in Europe (Birmingham, London, Naples) and in Australia (3 times in Melbourne, with the last event on November 2016 being the most catastrophic epidemic of asthma attacks induced by a thunderstorm [ 9 deaths and 8500 patients visiting the emergency department in a day]) [37], during the pollen season and thunderstorms are now recognized as a risk factor for asthma attacks in patients with pollen allergy (Table 2) [35-37].

Thunderstorms can concentrate pollen grains at ground level, thus leading to the release of allergenic particles of respirable size into the atmosphere after their rupture by osmotic shock. During the first 20-30 minutes of a thunderstorm, patients with pollen allergy may inhale a high concentration of the allergenic material that is dispersed into the atmosphere [35-37].

Consequently, individuals affected by pollen allergy should be alert to the danger of being outdoors without correct treatment of rhinitis and asthma during a thunderstorm in the pollen season.

Table 2. Characteristics of Described Epidemics of ThunderstormAssociated Asthma [References 29-35]

\footnotetext{
- The occurrence of epidemics is strictly linked to thunderstorms.

- Thunderstorm-related asthma epidemics occur during late spring and summer, when there are high atmospheric concentrations of airborne pollen grains-

- Epidemics do not include persons with pollinosis, who stay indoors with windows closed during thunderstorms.

- Levels of gaseous and particulate components of air pollution are not high during epidemics.

- There is a major risk for asthma in patients who are not under appropriate antiasthma treatment.

- Patients with allergic rhinitis and no previous asthma can experience bronchoconstriction, which is sometimes severe
} 
Measures to Improve Outdoor Air Quality and Reduce the Risk of Inhalation of Air Pollution

Much remains to be studied in this area, and biologic, genetic, epidemiologic, and clinical approaches to air pollution should be considered [38-41].

Governments worldwide and international organizations such as the World Health Organization and European Union are facing the growing problem of the respiratory effects induced by gaseous and particulate pollutants from motor vehicle emissions. The latest release of the Intergovernmental Panel on Climate Change [3] stated that climate change is very likely due to human activity, according to an impressive amount of data published in recent years. In addition, policymakers seem to have realized the importance of preventive measures (eg, Kyoto Protocol) and alternative energy sources. Desirable positive effects of these measures may be achieved in the coming decades, although, presumably, global temperature will continue to increase in the short term.

Wearing personal protective equipment (N95 mask or equivalent) might prove useful for avoiding the detrimental effect of air pollutants. Masks have proven useful in reducing respiratory virus transmission during a pandemic and can also help people to prevent adverse effects from vehicular pollution. However, more studies are needed to demonstrate their real utility $[1,3]$.

\section{The Farm Environment and Risk of Asthma}

The Amish and Hutterites are American farming populations whose lifestyles are remarkably similar in many respects but whose farming practices are different; the former follow traditional farming practices, whereas the latter use industrialized farming practices. Striking disparities in the prevalence of asthma have been observed between these populations, and little is known about the immune responses underlying these disparities. Stein et al [42] studied environmental exposure, genetic ancestry, and immune profiles among 60 Amish and Hutterite children by measuring levels of allergens and endotoxins and assessing the microbiome composition of indoor dust samples. Whole blood was collected to measure serum IgE levels, cytokine responses, and gene expression, and peripheral-blood leukocytes were phenotyped with flow cytometry. The effects of dust extracts obtained from Amish and Hutterite homes on immune and airway responses were assessed in a murine model of experimental allergic asthma. Despite the similar genetic ancestries and lifestyles of Amish and Hutterite children, the prevalence of asthma and allergic sensitization was 4 and 6 times lower in the Amish, whereas median endotoxin levels in Amish house dust were 6.8 times higher than in Hutterite house dust. Differences in microbial composition were also observed in dust samples from Amish and Hutterite homes. Profound differences in the proportions, phenotypes, and functions of innate immune cells were found between the 2 groups of children. In a mouse model of experimental allergic asthma, intranasal instillation of dust extracts from Amish — but not Hutterite - homes significantly inhibited airway hyperreactivity and eosinophilia. The results of the study of Stein et al in humans and mice indicate that the Amish environment induces protection against asthma by engaging and shaping the innate immune response.

While the burning of fossil fuels accounts for roughly $75 \%$ of world carbon dioxide emissions, deforestation is the second largest source [43]. Forests play a major role in controlling greenhouse gases by absorbing $\mathrm{CO}_{2}$ during photosynthesis. When forests are cut down, the planet's ability to absorb what humans emit is reduced [43].

\section{Conclusions}

Climate change modifies the production and dispersion of chemical and biologic components of atmospheric air pollution. In particular, the atmospheric allergen content of pollen and spores is increased, with proinflammatory effects on the airways of allergic patients. In other words, a body of evidence suggests that the world is undergoing major changes that involve the atmosphere and associated climate $[1,11,12-$ 14,35-39]. These changes, including global warming induced by human activity, have an impact on the biosphere and on the human environment. Global changes in population growth and demands, air pollution, and increased temperature of the earth are unprecedented and are threatening the future of human life. These changes are also leading to a redistribution of life on earth, thus posing risks in several areas, including economic development, livelihood, food safety, and global health. Increased production and concentration of aeroallergens and air pollutants and changes in their geographical distribution accompanied by changes in climate and weather patterns are among the observed and predicted consequences. Although most of the environmental changes that have occurred already are irreversible, there is still time to take action. One of the major challenges is the reduction in greenhouse gas emissions, some of which are also air pollutants. However, public health approaches to decreasing citizens' exposure to air pollution must be implemented, considering that it is important to reduce the use of fossil fuels, reduce private traffic in towns, improve public transport, and favor pedestrian traffic. Moreover, it is important also to plant nonallergenic trees in cities. The annual destruction of thousands of hectares of forest by fires, many of which are set with criminal intent, will also affect the future of our planet [43].

\section{Key Points}

- Asthma is a heterogeneous disease that is strongly influenced by environmental factors such as meteorological events and climate change, which vary in type and intensity across the world.

- Exposure to climate change and air pollution is linked to many signs of obstructive respiratory diseases (eg, asthma exacerbation), increased medication use, visits to the emergency department, and hospital admissions.

- Vehicular pollution in particular degrades the quality of air in urban areas, and industrial pollution still constitutes the largest source of air pollution in countries undergoing industrialization.

- In the last 50 years, $50 \%$ of rainforests on the planet have been destroyed. The annual destruction or deterioration 
of 13 million hectares of forest aggravates climate change.

- Persons affected by pollen allergy should be alert to the danger of being outdoors without correct treatment of rhinitis and asthma during a thunderstorm in the pollen season.

\section{Funding}

The authors declare that no funding was received for the present study.

\section{Conflicts of Interest}

The authors declare that they have no conflicts of interest.

\section{Previous Presentations}

Data from this study were presented in part by Professor Gennaro D'Amato as an invited speaker at a plenary session of the National Congress of the Spanish Society of Allergology and Clinical Immunology (SEAIC) in Murcia, Spain, in Murcia (October 26-28, 2017).

\section{References}

1. D'Amato G, Holgate ST, Pawankar R, Ledford DK, Cecchi L, AlAhmad $M$, et al. Meteorological conditions, climate change, new emerging factors, and asthma and related allergic disorders. A statement of the World Allergy Organization. World Allergy Organ J. 2015;8:25.

2. Orru H, Ebi KL, Forsberg B. The Interplay of Climate Change and Air Pollution on Health. Curr Environ Health Rep. 2017:4:504-13.

3. Intergovernmental Panel on Climate Change. 2014 IPCC fifth assessment report: climate change. Cambridge, UK and New York: Cambridge University Press [Accessed 1 February 2016].

4. Annesi-Maesano I. United nations Climate change Conferences: COP21 a lost opportunity for asthma and allergies and preparing COP 22. J Allergy Clin Immunol. 2016;136:57-8.

5. Sheehan WJ, Gaffin JM, Peden DB, Bush RK, Phipatanakul W. Advances in Environmental and Occupational Disorders 2016. J Allergy Clin Immunol. 2017;140:1683-92.

6. Crowley RA. Climate change and health: a position paper of the American College of Physicians. Ann Intern Med. 2016;164:608-10.

7. Global Initiative for asthma GINA. www.ginasthma.org. 2017.

8. Global initiative for COPD- GOLD. www.goldcopd.org. 2017.

9. Stach A, García-Mozo H, Prieto-Baena JC, Czarnecka-Operacz $M$, Jenerowicz $D$, Silny $W$. Prevalence of Artemisia species pollinosis in western Poland: impact of climate change on aerobiological trends, 1995-2004. J Investig Allergol Clin Immunol. 2007;17:39-47.

10. Yang IV, Lozupone CA, Schwartz DA. The environment, epigenome, and asthma. J Allergy Clin Immunol. 2017;140:14-23.

11. Xu-Qin Jiang, Xiao-Dong Mei. Air pollution and chronic airway diseases: what should people know and do? J Thorac Dis 2016;8:E31-E40.

12. D'Amato G, Vitale C, Lanza M, Molino A, D'Amato M. Climate change, air pollution, and allergic respiratory diseases: an update. Curr Opin Allergy Clin Immunol. 2016;16:434-40.
13. D'Amato G, Vitale C, De Martino A, Viegi G, Lanza M, Molino $A$, et al. Effects on asthma and respiration allergy of climate change and air pollution. Multidiscip Respir Med. 2015;10:39.

14. D'Amato G, Pawankar R, Vitale C, Lanza M, Molino A, Stanziola $A$, et al. Climate change and Air pollution: effects on respiratory allergy. Allergy Asthma Immunol Res. 2016;8:3915.

15. Powell P, Brunekreef B, Grigg J . How do you explain the risk of air pollution to your patients? Breathe. 2016;12:201-3.

16. D'Amato G, Cecchi L, D'Amato M, Liccardi G. Urban air pollution and climate change as environmental risk factors of respiratory allergy: an update. J Investig Allergol Clin Immunol. 2010;20:95-102.

17. Loxham M, Davies DE. Phenotypic and genetic aspects of epithelial barrier function in asthmatic patients. J Allergy Clin Immunol. 2017;139:1736-51.

18. Watts N, Amann M, Ayeb-Karlsson S, Belesova K, Bouley T, Boykoff $M$, et al. The Lancet Countdown on health and climate change: from 25 years of inaction to a global transformation for public health. Lancet. 2017;391:581-630.

19. Sénéchal H, Visez N, Charpin D, Shahali Y, Peltre G, Biolley JP, et al. A Review of the Effects of Major Atmospheric Pollutants on Pollen Grains, Pollen Content, and Allergenicity. The Scientific World Journal Hindawi Publishing Corporation. 2015.

20. Neophytou AM, White MJ, Oh SS, Thakur N, Galanter JM, Nishimura KK, et al. Air Pollution and Lung Function in Minority Youth with Asthma in the GALA II (Genes-Environments and Admixture in Latino Americans) and SAGE II (Study of African Americans, Asthma, Genes, and Environments) Studies. Am J Respir Crit Care Med. 2016;193:1271-80.

21. Loser S, Gregory LG, Zhang Y, Schaefer K, Walker SA, Buckley J, et al. Pulmonary ORMDL3 is critical for-induced allergic airways disease. J Allergy Clin Immunol. 2017;139:1496-1507.

22. Erzurum SC. New insights in oxidant biology in asthma. Ann Am Thorac Soc. 2016;13:S135-9

23. Bowatte G, Lodge CJ, Knibbs LD, Lowe AJ, Erbas B, Dennekamp $M$, et al. Traffic -related air pollution exposure is associated with allergic sensitization, asthma, and poor lung function in middle age. J Allergy Clin Immunol. 2017;139:122-9.

24. Schleimer RP, Berdnikovs S. Etiology of epithelial barrier dysfunction in patients with type 2 inflammatory diseases. J Allergy Clin Immunol. 2017;139:1752-61.

25. Pavord JD, Beasley FR, Agusti A, Anderson GP, Bel E, Brusselle G. After asthma: redefining airways diseases. Lancet. 2017;391:350-400.

26. Bartra J, Mullol J, del Cuvillo A, Dávila I, Ferrer M, Jáuregui I, et al. Air pollution and allergens. J Investig Allergol Clin Immunol. 2007;17:\$2:3-8.

27. Carlsten C, Blomberg A, Pui M, Sandstrom T, Wong SW, Alexis $N$, et al. Diesel exhaust augments allergen induced lower airway inflammation in allergic individuals: a controlled human exposure study. Thorax. 2016;71:35-44.

28. Chung HY, Hsieh CJ, Tseng CC, Yiin LM. Association between the first occurrence of allergic rhinitis in preschool children and air pollution in Taiwan. Int J Environ Res Public Health. 2016;13:268.

29. Beck I, Jochner S, Gilles S, McIntyre M, Buters JT, Schmidt-Weber $C$, et al. High environmental ozone levels lead to enhanced allergenicity of birch pollen. PLoS One. 2013;8:e80147. 
30. Malig BJ, Pearson DL, Chang YB, Broadwin R, Basu R, Green $R S$, et al. A time-stratified case-crossover study of ambient ozone exposure and emergency department visits for specific respiratory diagnoses in California (2005-2008). Environ Health Perspect. 2016;124:745-53.

31. Bellomo R, Gigliotti P, Treloar A, Holmes P, Suphioglu C, Singh $M B$, et al. Two consecutive thunderstorm associated epidemic of asthma in Melbourne. Med J Aust. 1992;156:834-7.

32. Taylor PE, Hagan R, Valenta R, Glovsky MM. Release of allergens in respirable aerosols: a link between grass pollen and asthma. J Allergy Clin Immunol. 2002;109:51-6.

33. Packe GE, Ayres JG. Asthma outbreak during a thunderstorm. Lancet. 1985;2:199-204.

34. Marks GB, Colquhoun JR, Girgis ST, Hjelmroos Koski $M$, Treoloar ABA, Hansen $P$, et al. Thunderstorm outflows preceding epidemics of asthma during spring and summer. Thorax. 2001;56:468-71.

35. D'Amato G, Vitale C, Lanza M, D'Amato M. Near fatal asthma: treatment and prevention. Eur Ann Allergy Clin Immunol. 2016;48:116-22.

36. D'Amato G, Vitale C, D'Amato M, Cecchi L, Liccardi G, Molino $A$, et al. Thunderstorm-related asthma: what happens and why. Clin Exp Allergy. 2016;46:390-6.

37. D'Amato G, Annesi Maesano I, Molino A, Vitale C, D'Amato M. Thunderstorm-related asthma attacks. J Allergy Clin Immunol. 2017;139:1786-7.

38. Bousquet J, O'Hehir RE, Anto JM, D'Amato G, Mösges R, Hellings PW, et al. Assessment of thunderstorm-induced asthma using Google Trends. J Allergy Clin Immunol. 2017;140:891-3.

39. Reddel HK, Sawyer SM, Everett PW, Flood PV, Peters MJ. Asthma control in Australia: a cross-sectional web based survey in a nationally representative population. Med J Aust. 2015;202:1750-6.
40. Kicic A, Stevens PT, Sutanto EN, Kicic A, Stevens PT, Sutanto EN, et al. Impaired airway epithelial cell responses from children with asthma to rhinoviral infection. Clin Exp Allergy. 2016;46:1441-55

41. Tay TR, Abramson MJ, Hew M. Closing the million patient gap of uncontrolled asthma. Med J Aus. 2016;204:216-7.

42. Stein MM, Hrusch CL, Gozdz J, Igartua C, Pivniouk V, Murray $\mathrm{SE}$, et al. Innate Immunity and Asthma Risk in Amish and Hutterite Farm Children. N Engl J Med. 2016;375:411-21.

43. D'Amato G, Vitale C, Rosario N, Neto HJC, Chong-Silva DC, Mendonça $F$, et al. Climate change, allergy and asthma, and the role of tropical forests. World Allergy Organization J. 2017;10:11.

\section{Manuscript received December 13, 2017; accepted for publication January 5, 2018.}

\section{- Gennaro D'Amato}

Division of Respiratory and Allergic Diseases

Department of Respiratory Diseases

High Specialty Hospital A.Cardarelli Napoli Italy

University of Napoli Federico II

School of Specialization in Respiratory Diseases

Via Rione Sirignano, 10

80121 Napoli, Italy

E-mail: gdamatomail@gmail.com 